\title{
IMPLEMENTASI PROBLEM BASED LEARNING UNTUK MENINGKATKAN HASIL BELAJAR SISWA KELAS XI JURUSAN TKR SMK NEGERI 2 YOGYAKARTA
}

\author{
Eko Nurbiyanto \\ SMK Muhammadiyah I Sleman, Yogyakarta \\ Email : eko.nurbiyanto90@gmail .com
}

\begin{abstract}
This research aims to increase students learning outcomes of class XI TKR 4 in the PKKR at SMK N 2 Yogyakarta through the application of the Problem Based Learning model. The types of this research are Classroom Action Research (CAR). The research data retrieval is on January 7 , 2019 until February 9, 2019 at SMK N 2 Yogyakarta. The research was carried out in 2 cycles where each cycle was 2 times meeting. The research subjects were students of class XI TKR 4 on the Pemeliharaan Kelistrikan Kendaraan Ringan (PKKR) subjects in the 2018/2019 academic year with a total of 21 students. Data collection is done by test, observation, and documentation. Data processing is done quantitatively by seeing the implementation of the Problem Based Learning (PBL) model and learning outcomes in each cycle. The success criteria determined are minimum $80 \%$ of students have reached the Minimum Completion Criteria (KKM) which is a minimum value of 76.00. The results of this research showed that the application of the Problem Based Learning (PBL) model is able to increase the learning outcomes of students in class XI TKR 4 in PKKR subjects at SMK N 2 Yogyakarta. The percentage of student who achieve KKM increase to $66.67 \%$ in the first cycle and $85.71 \%$ in the second cycle.
\end{abstract}

Keywords: Problem Based Learning, Learning Outcomes, PKKR

\begin{abstract}
Abstrak
Penelitian ini bertujuan untuk meningkatkan hasil belajar siswa kelas XI TKR 4 pada mata pelajaran PKKR di SMK N 2 Yogyakarta melalui penerapan Problem Based Learning. Penelitian ini adalah Penelitian Tindakan Kelas (PTK). Pengambilan data penelitian dilakukan pada 7 Januari 2019 sampai dengan 9 Februari 2019 di SMK N 2 Yogyakarta. Penelitian dilaksanakan dalam 2 siklus yang masing-masing siklus terdiri dari 2 kali pertemuan. Subjek penelitiannya adalah siswa kelas XI TKR 4 pada mata pelajaran Pemeliharaan Kelistrikan Kendaraan Ringan (PKKR) semester genap tahun ajaran 2018/2019 dengan jumlah 21 siswa. Data diambil melalui tes, observasi, dan dokumentasi. Pengolahan data dilakukan secara kuantitatif dengan melihat pelaksanaan model pembelajaran Problem Based Learning (PBL) dan hasil belajar pada setiap siklusnya. Kriteria keberhasilan yang ditentukan adalah minimal 80\% siswa mencapai Kriteria Ketuntasan Minimal (KKM) dengan nilai minimal 76,00. Hasil penelitian menunjukan bahwa penerapan model pembelajaran Problem Based Learning (PBL) mampu meningkatkan hasil belajar siswa kelas XI TKR 4 pada mata pelajaran PKKR di SMK N 2 Yogyakarta. Persentase siswa yang mencapai KKM meningkat menjadi 66,67\% pada siklus I dan $85,71 \%$ pada siklus II.
\end{abstract}

Kata kunci : Problem Based Learning, Hasil Belajar, PKKR

\section{PENDAHULUAN}

Dewasa ini tenaga kerja dituntut untuk mampu mengembangkan diri sesuai dengan perkembangan teknologi yang sangat pesat. Terlebih lagi pada tanggal 31 Desember 2015 


\section{Eko Nurbiyantoro}

seluruh negara anggota ASEAN menyepakati diberlakukannya Masyarakat Ekonomi ASEAN (MEA) atau ASEAN Ekonomic Community (AEC) untuk meningkatkan kerjasama bidang perekonomian di kawasan Asia Tenggara. Indonesia merupakan negara di kawasan Asia Tenggara yang ikut ambil bagian dalam MEA 2015. Tujuan MEA tersebut salah satunya adalah kebebasan mobilitas tenaga kerja terlatih di kawasan Asia Tenggara.

Peningkatan kualitas tenaga kerja selalu diupayakan disetiap negara. Pendidikan untuk menghasilkan tenaga kerja yang terlatih di Indonesia salah satunya adalah Sekolah Menengah Kejuruan (SMK). Dalam UU Nomer 20 tahun 2003 jenis pendidikan yaitu pendidikan umum, pendidikan kejuruan, pendidikan akademik, pendidikan profesi, pendidikan vokasi, pendidikan keagamaan dan pendidikan khusus. SMK termasuk pendidikan kejuruan ditingkat menengah yang menyiapkan peserta didik untuk diprioritaskan bekerja di dunia industri.

Sekolah Menengah Kejuruan (SMK) menyiapkan dan membekali peserta didiknya dengan pengetahuan keterampilan yang dibutuhkan di dunia industri. Peserta didik SMK dibekali dengan kemampuan yang berupa hard skill dan soft skill yang dibutuhkan sesuai jurusannya. Degan tujuan dan proses pembelajaran yang bersifat demikian maka pembelajaran SMK harus disesuaikan dengan kebutuhan industri dan mengikuti perkembangan teknologinya. Penerapan pembelajaran yang disesuaikan dengan kebutuhan industri diharapkan mampu menghasilkan output siswa yang memiliki kompetensi dan siap untuk masuk dunia industri.Untuk mencapai kualitas output lulusan yang baik maka SMK harus menerapkan proses pembelajaran yang tepat. Proses pembelajaran dan kompetensi yang dimiliki siswa akan tercermin dari hasil belajar siswanya.

SMK N 2 Yogyakarta adalah Sekolah Menengah Kejuruan yang berbasis teknologi yang mempersiapkan peserta didiknya untuk menjadi tenaga kerja profesional di dunia industri dengan kompetensi yang dimiliki sesuai jurusannya. Sesuai dengan visinya yaitu menjadi lembaga pendidikan yang berkarakter dan berwawasan lingkungan yang menghasilkan tamatan profesional, mampu berwirausaha, beriman dan bertaqwa. Dari visi tersebut harapannya SMK N 2 Yogyakarta mampu menghasilkan lulusan yang kompeten, profesional, beriman dan bertaqwa.

Dalam hasil observasi selama berjalannya Praktek Lapangan Terbimbing (PLT) yang dilaksanakan pada bulan September 2018 sampai dengan November 2018 didapatkan permasalahan pertama yaitu nilai Ulangan Harian (UH) mata pelajaran Pemeliharaan Kelistrikan Kendaraan Ringan (PKKR) siswa kelas XI TKR 4 SMK N 2 Yogyakarta, yaitu tertinggi adalah 70,00 dan terendah 35,00 dengan rata-rata nilai kelas yaitu 49,33. SMK N 2 
Yogyakarta memiliki Kriteria Ketuntasan Minimal (KKM) 76,00 untuk semua mata pelajarannya. Dari nilai yang demikian berarti pada mata pelajaran teori PKKR tidak ada nilai yang mencapai KKM atau 100\% siswanya belum lulus KKM.

Permasalahan hasil belajar selanjutnya adalah hasil Penilaian Tengah Semester (PTS) PKKR kelas XI TKR SMK N 2 Yogyakarta. Dari empat kelas yaitu kelas XI TKR 1, XI TKR 2, XI TKR 3 dan XI TKR 4 dengan total 115 siswa yang mengikuti PTS didapatkan hasil rerata nilai 56,17. Dari empat kelas tersebut hanya ada 5 siswa XI TKR 2 yang mampu mencapai KKM. Pada kelas XI TKR 1, XI TKR 3 dan XI TKR 4 tidak ada siswa yang nilainya mencapai KKM. Artinya hanya 4,35 \% siswa yang nilai PTSnya sudah mencapai KKM.

Selain hasil belajar yang kurang maksimal ditemukan permasalahan lain saat proses pembelajan teori. Pada saat guru menyampaikan materi di depan kelas ada beberapa orang siswa yang duduk paling belakang bermain Handphone, beberapa siswa yang lain terlihat sangat mengantuk bahkan sesekali tertidur. Selain itu partisipasi siswa saat proses pembelajaran juga masih sedikit, tercatat hanya ada 2 siswa yang bertanya tentang materi kepada guru dan siswa harus diperintah untuk mencatat materi yang penting serta malu untuk menanggapi pertanyaan guru. Dari data observasi diatas terlihat bahwa siswa kurang aktif dalam proses pembelajaran seperti bertanya, berdiskusi, dan mengutarakan jawaban sesuai pendapatnya.

Permasalahan yang ditemukan dalam proses pembelajaran selanjutnya adalah pada saat guru menanya kembali materi yang telah disampaikan dipertemuan sebelumnya, siswa tidak mampu menjawab dan terlihat kebingungan. Hal ini menunjukan bahwa kesiapan siswa untuk mengikuti pembelajaran masih kurang. Guru sebelum memulai proses pembelajaran untuk masuk ke materi yang baru guru harus selalu mengulang materi yang lalu dengan waktu yang cukup lama karena siswa yang belum siap mengikuti pembelajaran, sehingga waktu pembelajaran teori terpotong.

Proses pembelajaran yang demikian kurang tepat dengan apa yang diharapkan dari kurikulum 2013 yang diterapkan di SMK N 2 Yogyakarta. Kurikulum 2013 menuntut proses pembelajaran yang berpusat pada siswa (student centered). Pada kurikulum 2013 banyak melibatkan siswa untuk ikut berperan aktif dalam proses pembelajaran. Siswa dituntut banyak bertanya bukan untuk ditanya. Selain itu siswa dituntut mencari pengetahuan dari berbagai sumber.

Dari uraian diatas, permasalahan yang sangat penting untuk segera diatasi adalah rendahnya hasil belajar. Hasil belajar merupakan output dari sebuah proses pembelajaran. 
Hasil belajar dapat digunakan sebagai ukuran keberhasilan pelaksanaan proses pembelajaran. Proses belajar yang baik maka akan menghasilkan nilai hasil belajar siswa yang baik. Apabila hasil belajar masih kurang baik, maka dapat dikatakan bahwa kualitas proses pembelajarannya kurang bagus. Berdasarkan dari hasil observasi awal didapati bahwa hasil belajar siswa kelas XI TKR 4 masih terbilang buruk, terbukti dari hasil Ulangan Harian belum ada siswa yang mencapai KKM 76,00 dan Penilaian Tengah Semester hanya 5 siswa yang telah mencapai KKM, sehingga harus segera diatasi. Hal ini mendorong dilakukannya sebuah tidakan pada proses pembelajaran yang mampu meningkatkan kualitas pembelajaran sehingga dapat meningkatkan hasil belajar siswa.

Permasalahan kurangnya hasil belajar dapat dimungkinkan karena model pembelajaran yang diterapkan kurang tepat, sehingga diperlukan suatu model pembelajaran yang sesuai atau sejalan dengan diterapkannya kurikulum 2013 di SMK N 2 Yogyakarta. Metode yang akan diterapkan ini harapannya mampu mengarahkan siswa menuju mindset pembelajaran student centered yang mana akan melibatkan siswa untuk aktif dalam proses pembelajaran sehingga terjadi pembelajaran yang interaktif dan mampu meningkatkan hasil belajar siswa. Dengan terciptanya pembelajaran yang interaktif dan menyenangkan maka guru juga mendapat kemudahan untuk menguasai atau mengondisikan situasi kelas.

Berdasarkan kajian teori ada dua hal yang berhubungan dengan proses pembelajaran yang mampu meningkatkan hasil belajar yaitu model atau penyajian materi pelajaran dan suasana pelajaran. Suasana pembelajaran juga dapat dipengaruhi dengan pemilihan model pembelajaran. Model pembelajaran yang menyenangkan, tidak membosankan, menarik dan mudah dipahami akan meningkatkan hasil belajar siswa. Selain itu suasana belajar yang tenang, terjadinya dialog yang kritis antara siswa dengan guru, dan menumbuhkan suasana aktif diantara siswa juga mampu meningkatkan hasil belajar siswa.

Problem Based Learning (PBL) merupakan model pembelajaran yang berbasis pada permasalahan. Siswa dituntun untuk belajar dengan memecahkan suatu permasalahan yang diberikan oleh guru. Pengembangan cara berfikir siswa, kerjasama, interaksi positif dan terciptanya suasana kondusif dari penerapan PBL diharapkan mampu meningkatkan kualitas pembelajaran sehingga hasil belajar pun akan meningkat. PBL juga merupakan model pembelajaran yang sesuai diterapkan pada SMK dengan kurikulum 2013.

Berdasarkan Modul Pelatihan dan Pendampingan Implementasi Kurikulum 2013 Sekolah Menengah Kejuruan pada materi Analisis Penerapan Model Pembelajaran dari Direktorat Pembinaan Sekolah Menengah Kejuruan, Direktorat Jendral Pendidikan Dasar dan Menengah, Kementrian Pendidikan dan Kebudayaan 2018 yang menyatakan bahwa "guna 
memperkuat pendekatan saintifik, pendekatan rekayasa dan teknologi serta mendorong kemampuan peserta didik menghasilkan karya nyata, baik individual maupun kelompok, maka dapat diterapkan strategi pembelajaran menggunakan model pembelajaran yang salah satunya adalah Problem Based Learning".

Model pembelajaran PBL memiliki keunggulan sebagai berikut.

1) Merupakan teknik yang cukup bagus untuk lebih memahami isi pembelajaran.

2) Dapat menantang kemampuan siswa serta memberikan kepuasan untuk menemukan pengetahuan baru bagi siswa.

3) Meningkatkan aktivitas belajar siswa.

4) Dapat membantu siswa bagaimana mentransfer pengetahuan mereka untuk memahami masalah dalam kehidupan nyata.

5) Dapat membantu siswa untuk mengembangkan pengetahuan barunya dan bertanggungjawab dalam pembelajaran yang mreka lakukan

6) Cara berfikir siswa berkembang, karena belajar bukan hanya dari guru.

7) Lebih menyenangkan dan disukai siswa.

8) Mengembangkan kemampuan berfikir kritis.

9) Mampu memberikan kesempatan bagi siswa untuk mengaplikasikan pengetahuan mereka di dunia nyata.

10) Mengembangkan minat belajar siswa secara terus-menerus.

Dengan diterapkanya metode pembelajaran yang interaktif dan melibatkan siswanya untuk berperan aktif dalam proses pembelajaran seperti keunggulan PBL tersebut, diharapkan mampu meningkatkan hasil belajar siswa pada mata pelajaran PKKR kelas XI TKR di SMK N 2 Yogyakarta. Siswa yang mengikuti proses pembelajaran dengan metode PBL dengan baik diharapkan memiliki output hasil belajar yang meningkat.

\section{METODE}

Penelitian ini merupakan Penelitian Tindakan Kelas (PTK) dengan menerapkan Problem Based Learning (PBL) untuk meningkatkan hasil belajar siswa. Model PTK yang digunakan adalah spiral Kemmish dan Mc. Taggart. Tempat penelitian adalah di SMK Negeri 2 Yogyakarta, tepatnya di Jl. AM. Sangaji 47 Yogyakarta. Pengambilan data penelitian ini dilaksanakan pada tanggal 7 Januari sampai 9 Februari 2019. Penelitian ini menggunakan subyek siswa jurusan Teknik Kendaraan Ringan SMK N 2 Yogyakarta. Adapun lebih spesifiknya adalah siswa kelas XI TKR 4 yang mengikuti mata pelajaran Perawatan Kelistrikan Kendaraan Ringan (PKKR) pada semester genap tahun ajaran 2018/2019. Jumlah 
siswa dalam satu kelas yaitu 21 siswa. Dalam penelitian ini yang menjadi objek penelitian adalah model pembelajaran Problem Based Learning dan hasil belajar siswa kelas XI TKR 4 pada mata pelajaran PKKR di SMK N 2 Yogyakarta.

Teknik pengumpulan data dalam penelitian ini adalah observasi, tes, dan dokumentasi. Observasi dilakukan menggunakan lembar observasi untuk mengamati pelaksanaan PBL. Tes dilaksanakan untuk mengukur kemampuan pemahaman siswa tentang materi yang telah disampaikan dengan menggunakan soal tes. Dokumentasi dilaksanakan untuk menyimpan berkas dan foto kegiatan selama proses pembelajaran saat penelitian berlangsung. Pada penelitian ini menggunakan dua macam pengujian validitas instrumen yaitu validitas konstruk (Contruct Validity) dan validitas isi (Content validity). Pengujian validitas dilakukan dengan meminta pendapat ahli (judgment expert) untuk dimintai pertimbangan apakah instrukmen sudah layak digunakan atau perlu beberapa perbaikan, serta dilakukan dengan membandingkan antara isi instrumen dengan materi pelajaran yang telah diajarkan.

Teknik analisis data yang digunakan adalah presentase keberhasilan penerapan PBL, ketuntasan kelas (presentase jumlah siswa yang telah lulus KKM), dan rata-rata hasil belajar siswa. Adapun rumus yang digunakan adalah sebagai berikut.

$$
\begin{gathered}
\text { Tingkat keberhasilan PBL (\%) } \\
=\frac{\text { Jumlah poin terlaksana }}{\text { Jumlah seluruh poin }} \times 100 \% \\
\text { Ketuntasan kelas }(\%) \\
=\frac{\text { jumlah siswa KKM }}{\text { total siswa }} \times 100 \% \\
\text { Rata-rata hasil belajar } \\
\overline{\mathrm{x}}=\frac{\Sigma \mathrm{x}}{\mathrm{n}}
\end{gathered}
$$

\section{HASIL PENELITIAN DAN PEMBAHASAN}

\section{Hasil Penelitian}

1) Pelaksanaan model PBL

Penelitian yang dilaksanakan sebanyak 2 siklus ini selalu dilakukan pengamatan terkait pelaksanaan pembelajaran dengan menggunakan model PBL. Adapun 
hasil persentase keberhasilan pelaksanaan PBL dari 4 kali pertemuan tersebut adalah sebagai berikut.

Tabel 1. Persentase keberhasilan pelaksanaan PB

\begin{tabular}{clc}
\hline No & Pelaksanaan & Hasil (\%) \\
\hline 1 & Siklus I pertemuan 1 & 72,73 \\
2 & Siklus I pertemuan 2 & 75 \\
3 & Siklus II pertemuan 1 & 100 \\
4 & Siklus II pertemuan 2 & 100 \\
\hline
\end{tabular}

Apabila dilihat dalam bentuk grafik peningkatan persentase keberhasilan pelaksanaan PBL maka hasilnya adalah sebagai berikut.

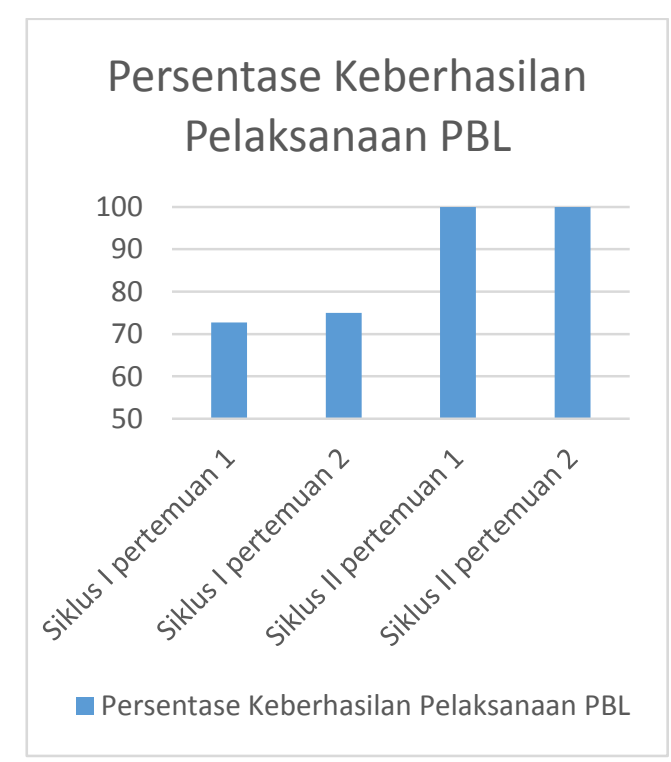

Gambar 1. Persentase keberhasilan pelaksanaan PBL

2) Hasil belajar siswa

Hasil belajar siswa terlihat dari nilai post-test pada siklus I dan siklus II.

Hasilnya adalah sebagai berikut.

Tabel 2. Hasil belajar siswa terlihat dari nilai post-test pada siklus I dan siklus II

\begin{tabular}{clccc}
\hline No & Hasil Belajar & Data Awal & Siklus I & Siklus II \\
\hline 1 & Tertinggi & 70,00 & 88,00 & 96,00 \\
2 & Terendah & 35,00 & 68,00 & 44,00 \\
3 & KKM & 76,00 & 76,00 & 76,00 \\
4 & $\geq$ KKM & 0 & 14 & 18
\end{tabular}




\begin{tabular}{llccc}
5 & $<\mathrm{KKM}$ & 21 & 7 & 3 \\
6 & Rerata & 49,33 & 77,33 & 83,81 \\
7 & Persentase ketuntasan kelas & $0 \%$ & $66,67 \%$ & $85,71 \%$ \\
\hline
\end{tabular}

\section{Pembahasan}

1. Pelaksanaan Model Problem Based Learning

Pada penelitian yang dilaksanakan sebanyak 2 siklus ini selalu dilakukan pengamatan terkait pelaksanaan pembelajaran dengan menggunakan model PBL. Pengamatan dilakukan oleh observer terhadap model PBL yang diterapkan guru. Pelaksaan pembelajaran dengan model PBL diamati dan ditulis hasilnya pada checklist yang tertuang dalam lembar observasi PBL.

Siklus I pelaksanaan PBL masih belum maksimal, terbukti dari 2 kali pertemuan presentase keberhasilan PBLnya adalah $72,73 \%$ pada pertemuan 1 dan meningkat menjadi $75 \%$ pada pertemuan 2. Siklus I berjalan dengan kurang maksimal karena guru dan siswa belum terbiasa dengan model pembelajaran PBL sehingga masih memerlukan penyesuaian. Guru belum dapat melaksanakan seluruh poin PBL yang terdapat dalam lembar observasi.

Siklus II berjalan dengan lebih baik dan sudah maksimal karena adanya perbaikan berdasarkan refleksi pada siklus I, terbukti bahwa pada siklus II pertemuan 1 dan 2 sudah semua poin dalam lembar observasi PBL terlaksana, artinya presentase keberhasilan pelaksanaan PBLnya adalah 100\%. Pada siklus II dilaksanakan berdasarkan refleksi pada siklus I sebagai acuan untuk perbaikan. Pada siklus II pelaksanaan pembelajaran PBL sudah baik dan maksimal, terbukti dari poin pelaksanaan PBL pada lembar observasi yang sudah terpenuhi semua.

Penelitian ini adalah untuk meningkatkan hasil belajar siswa kelas XI TKR 4 di SMK N 2 Yogyakarta pada mata pelajaran PKKR melalui penerapan model Problem Based Learning (PBL). Menurut (Susanto, 2013:13-14) penerapan model pembelajaran yang menyenangkan, tidak membosankan, menarik dan mudah dipahami akan meningkatkan hasil belajar. Suasana belajar yang tenang, terjadi dialog kritis antara siswa dengan guru, dan menumbuhkan suasana aktif ini dapat terwujud salah satunya adalah karena adanya pemilihan model belajar yang tepat sehingga mampu memaksimalkan hasil belajar siswa.

PBL merupakan model pembelajaran yang berbasis pada permasalahan. Pembelajaran didesain berjalan sesuai dengan sintaks pembelajaran berbasis masalah. 
Siswa dituntut mampu memecahkan permasalahan yang diberikan oleh guru melalui diskusi kelompok. PBL mampu meningkatkan keaktifan siswa, lebih menyenangkan dan disukai siswa, mengembangkan cara berfikir siswa, meningkatkan kemampuan berfikir kritis, terjadinya interaksi positif antar peserta didik ataupun dengan guru. PBL juga merupakan salah satu model pembelajaran yang cocok diterapkan di SMK dengan kurikulum 2013.

Dengan pelaksanaan model pembelajaran Problem Based Learning (PBL) yang sudah baik dan maksimal harapanya mampu meningkatkan hasil belajar siswa. Hasil belajar dijadikan acuan peningkatan pemahaman siswa terkait materi pembelajaran yang disampaikan oleh guru.

2. Hasil belajar siswa

Hasil belajar merupakan permasalahan yang menjadi fokus utama penelitian ini. Penelitian ini bermaksud untuk meningkatkan hasil belajar siswa melalui penerapan model PBL. Hasil belajar didapatkan dari hasil post test yang diberikan kepada pada setiap ahir siklus.

Berdasarkan data observasi, hasil belajar selalu meningkat setiap siklusnya. Pada data awal yang diperoleh saat melaksanakan PLT hasil belajar siswa rata-ratanya adalah 49,33 dengan nilai terendah 35,00 dan nilai tertinggi 70,00. Pada siklus I yang dikenai model pembelajaran PBL rata-rata hasil belajar siswa adalah 77,33 dengan nilai terendah 68,00 dan nilai tertinggi 88,00. Terlepas dari belum maksimalnya pelaksanaan pembelajaran dengan model PBL pada siklus I, hasil belajar siswa sudah menunjukan adanya peningkatan. Kemudian pada siklus II yang dilaksanakan berdasarkan refleksi perbaikan dari siklus I rata-rata hasil belajarnya adalah 83,81 dengan nilai terendah 44,00 dan nilai tertinggi 96,00. Dengan hasil yang demikian maka dapat dilihat bahwa hasil belajar siswa semakin meningkat pada siklus II karena penerapan model PBL yang sudah maksimal.

Dilihat dari jumlah siswa yang mencapai KKM juga selalu meningkat setiap siklusnya. Pada data awal tidak ada siswa yang nilainya mencapai KKM, kemudian pada siklus I terdapat 14 siswa dan pada siklus II ada 18 siswa yang nilainya telah mencapai KKM. Dalam persentase ketuntasan kelasnya pada data awal adalah $0 \%$, kemudian meningkat menjadi $66,67 \%$ pada siklus I dan $85,71 \%$ pada siklus II. Karena terget ketuntasan kelas adalah $75 \%$ maka siklus dihentikan cukup sampai siklus II. 
3. Keberhasilan penerapan model PBL untuk meningkatkan hasil belajar

Hasil penelitian ini menunjukan bahwa penerapan model pembelajaran Problem Based Learning (PBL) pada mata pelajaran Pemeliharaan Kelistrikan Kendaraan Ringan (PKKR) dapat meningkatkan hasil belajar siswa kelas XI Teknik Kendaraan Ringan (TKR) 4 di SMK N 2 Yogyakarta. Peningkatannya terlihat dari rata-rata hasil belajar siswa serta ketuntasan kelasnya atau jumlah siswa yang telah lulus KKM.

Hasil belajar siswa pada siklus I ketuntasan kelasnya adalah 66,67\% siswa dan belum mencapai target $80 \%$ siswa lulus KKM. Hal ini dikarenakan pada siklus I pelaksanaan pembelajaran dengan model PBL juga belum maksimal, yaitu presentase keberhasilannya adalah $72,73 \%$ pada pertemuan 1 dan $75 \%$ pada pertemuan 2 . Siklus II dengan pelaksanaan PBL yang sudah $100 \%$ atau maksimal maka hasil belajar siswa pun semakin meningkat yaitu dengan presentase ketuntasan kelasnya adalah 85,71\% siswa.

Model Problem Based Learning merupakan model pembelajaran yang berbasis pada permasalahan. Menurut Sanjaya (2006:214) "Strategi Pembelajaran Berbasis Masalah (SPBM) dapat diartikan sebagai rangkaian aktivitas pembelajaran yang menekankan pada suatu proses penyelesaian masalah yang dihadapi secara ilmiah". Proses pembelajaran PBL didesain oleh guru agar siswa mampu menyelesaikan permasalahan secara ilmiah dari berbagai sumber melalui diskusi kelompok dengan temannya.

Pembelajaran yang demikian akan mengembangkan cara berfikir siswa untuk memecahkan sebuah permasalahan. Diskusi kelompok menjadi sarana yang tepat dalam aktivitas pemecahan masalah karena dengan diskusi siswa berinteraksi positif dengan siswa ataupun bisa juga dengan guru sebagai fasilitator. Diskusi juga melatih kemempuan siswa unutuk bekerjasama dengan temannya. Berjalannya proses pembelajaran yang demikian akan meningkatkan kualitas pembelajaran dan mampu meningkatkan hasil belajar siswa.

Keunggulan PBL (Hamdayama, 2017:17) yaitu : (1) peserta didik dilibatkan dalam kegiatan belajar, (2) peserta didik dilatih bekerjasama, (3) peserta didik memperoleh ilmu dari berbagai sumber. Peserta didik yang dilibatkan dalam proses pembelajaran (student centered) akan lebih memberikan kesan pada siswa sehingga proses pemahaman materi lebih mudah. Selain itu hal tersebut juga mampu mengurangi kejenuhan siswa saat belajar.

Hal positif dalam penerapan model PBL mampu meningkatkan hasil belajar siswa, terbukti dari hasil penelitian ini. Hasil penelitian ini juga mendukung penelitian 
yang relevan, yaitu implementasi Problem Based Learning mampu meningkatkan hasil belajar siswa. Hasil ini memperkuat hasil penelitian (Wibowo, 2013:83) yaitu PBL lebih efektif daripada model konvensional pada mata pelajaran Las Busur Listrik di SMK N 1 Seyegan. Hasil penelitian ini juga sejalan dengan penelitian (Wibawa, 2014:98) dan (Dwiyatmoko, 2018:113), bahwa penerapan PBL mampu meningkatkan hasil belajar siswa pada mata pelajaran Gambar Teknik Mesin di SMK Piri Sleman dan PCPT di SMK N 2 Yogyakarta. Data beberapa hasil penelitian tersebut mendukung bahwa model PBL memang layak dan tepat digunakan sebagai variasi model pembelajaran di SMK dan mampu meningkatkan hasil belajar siswanya.

\section{KESIMPULAN DAN SARAN}

\section{Kesimpulan}

Berdasarkan pada hasil dan pembahasan penelitian, maka dapat disimpulkan bahwa implementasi model pembelajaran Problem Based Learning (PBL) pada mata pelajaran PKKR kelas XI TKR 4 di SMK N 2 Yogyakarta mampu meningkatkan hasil belajar siswa. Terbukti dari hasil penelitian pada data nilai awal sebelum diterapkan PBL rata-ratanya 49,33 kemudian pada siklus I menjadi 77,33 dan ahirnya pada siklus II menjadi 83,81. Jika dilihat dalam presentasenya ketuntasan kelas pada data awal adalah $0 \%$, kemudian meningkat menjadi $66,67 \%$ pada siklus I dan $85,71 \%$ pada siklus II.

\section{Saran}

Untuk meningkatkan kualitas pembelajaran berdasarkan pada hasil penelitian ini maka berikut adalah beberapa saran yang dapat memperbaiki proses pembelajaran.

1. Bagi guru

a. Sebaiknya model pembelajaran Problem Based Learning (PBL) digunakan guru sebagai variasi model pembelajaran agar siswa tidak bosan dan mampu meningkatkan hasil belajarnya. Guru dapat menerapkan PBL pada saat pembelajaran teori.

b. Penerapan PBL pada KD yang serupa dapat dilakukan. Pada kompetensi dasar yang hampir serupa dengan apa yang ada pada penelitian ini maka ada baiknya menggunakan model Problem Based Learning ( $P B L)$ dengan ditambah inovasi lain yang lebih baik.

c. Diskusi kelompok mampu mendorong siswa untuk berfikir kritis dan bekerjasama sehingga baik untuk dilaksanaan saat proses pembelajaran. 
126 Eko Nurbiyantoro

2. Bagi siswa

a. Sebaiknya siswa selalu meningkatkan kesadaran tentang pentingnya belajar, sehingga selalu bersikap baik didalam kelas yang akan menciptakan suasana belajar yang kondusif.

b. Manfaatkan fasilitas buku dan internet di sekolah untuk kepentingan belajar sehingga fasilitas sekolah memiliki imbas positif terhadap kemajuan siswa dan sekolah. 